\title{
Determination of bacterial load by real-time PCR using a broad-range (universal) probe and primers set
}

\author{
Mangala A. Nadkarni, F. Elizabeth Martin, Nicholas A. Jacques \\ and Neil Hunter
}

Institute of Dental Research, Westmead Centre For Oral Health, Westmead Hospital, PO Box 533, Wentworthville, NSW 2145, Australia
Author for correspondence: Mangala A. Nadkarni. Tel: +6129485 7826. Fax: +61294857599. e-mail:mnadkarni@dental.wsahs.nsw.gov.au

The design and evaluation of a set of universal primers and probe for the amplification of 165 rDNA from the Domain Bacteria to estimate total bacterial load by real-time PCR is reported. Broad specificity of the universal detection system was confirmed by testing DNA isolated from 34 bacterial species encompassing most of the groups of bacteria outlined in Bergey's Manual of Determinative Bacteriology. However, the nature of the chromosomal DNA used as a standard was critical. A DNA standard representing those bacteria most likely to predominate in a given habitat was important for a more accurate determination of total bacterial load due to variations in 16S rDNA copy number and the effect of generation time of the bacteria on this number, since rapid growth could result in multiple replication forks and hence, in effect, more than one copy of portions of the chromosome. The validity of applying these caveats to estimating bacterial load was confirmed by enumerating the number of bacteria in an artificial sample mixed in vitro and in clinical carious dentine samples. Taking these parameters into account, the number of anaerobic bacteria estimated by the universal probe and primers set in carious dentine was $\mathbf{4 0}$-fold greater than the total bacterial load detected by culture methods, demonstrating the utility of real-time PCR in the analysis of this environment.

Keywords: real-time PCR (TaqMan), detection of bacteria, universal probe, rDNA copy number, carious dentine

\section{INTRODUCTION}

Culture dependent methods for enumerating bacterial numbers are known to be biased since bacteria can only be cultivated if their metabolic and physiological requirements can be reproduced in vitro. These techniques may take several days to yield a result and therefore are inappropriate in situations where rapid diagnostic decisions are required. Where complex fastidious microbial communities are under investigation, such as the variety of microbial habitats in the oral cavity, enumerating bacteria by traditional microbial culturing techniques may also produce erroneous results (Dymock et al., 1996; Kroes et al., 1999).

Abbreviations: ANGIS, Australian National Genomic Information Service; 6-FAM, 6-carboxyfluorescein; RTF, reduced transport fluid; TAMRA, 6carboxy-tetramethylrhodamine; $C_{T}$, threshold cycle; $T_{m}$, melting temperature of DNA; $t_{d}$, bacterial doubling time.
Fluorescence-based methods can also be used to enumerate bacteria. In the food and biotechnology industries, for instance, the automated counting of pure cultures by flow cytometry is well established (Veal et al., 2000). However, most bacteria are optically too similar to resolve from each other or from debris using flow cytometry, without artificially modifying the target bacteria using fluorescent labelling techniques such as fluorescent antibodies or fluorescent dyes (Veal et al., 2000; Attfield et al., 1999). Differences in bacterial cell size, coaggregation of bacteria and the presence of different contaminating matrices (e.g. mud, food, dental plaque, dentine) can also make meaningful counting difficult, if not problematic, by interference with direct, or fluorescence, microscopy (Veal et al., 2000).

Rapid enumeration of bacteria can also be achieved by using a variety of molecular approaches (Ward et al., 1990; Amann et al., 1995; Wintzingerode et al., 
1997; Hugenholtz et al., 1998). Primers with broad interspecies specificity have been designed to amplify $16 \mathrm{~S}$ rDNA by PCR and have been used to determine bacterial numbers in complex communities (Wilson et al., 1990; Relman et al., 1992; Greisen et al., 1994; Marchesi et al., 1998; Klausegger et al., 1999; Suzuki et al., 2000). A majority of these studies, however, report the use of more than a single set of primers to detect the bacteria of interest. Other techniques, such as competitive PCR (Blok et al., 1997; Rupf et al., 1999), are labour-intensive and require the analysis of results from multiple reactions for each test sample. In contrast, realtime PCR, such as the TaqMan system developed by Applied Biosystems, relies on the release and detection of a fluorescent signal following the cleavage of a fluorescent labelled probe by the $5^{\prime}$-exonuclease activity of Taq polymerase. In the intact state, the fluorescent signal on the probe, such as 6-carboxyfluorescein (6FAM), is quenched by the close proximity on the probe of a second dye, 6-carboxy-tetramethylrhodamine (TAMRA). The release of the fluorescent dye during each round of amplification allows for the rapid detection and quantification of DNA without the need for post-PCR processing, such as gel electrophoresis and radioactive hybridization (Heid et al., 1996). In addition, the in-built 96-well format greatly increases the number of samples that can be simultaneously analysed.

In theory, conserved regions of $16 \mathrm{~S}$ rDNA should provide the means for detecting and enumerating complex bacterial populations by real-time PCR, provided a universal probe can be constructed. However, the final determination of bacterial load by real-time PCR in a multi-species population will be influenced by the variation in the number of rRNA operons in a given species (Farelly et al., 1995). Bi-directional replication can further increase the numbers of a given rRNA operon, depending on the number of replication forks and the location of the rRNA operon relative to the origin of replication. The number of replication forks is directly related to the generation time, $t_{\mathrm{d}}$, which in turn depends on the metabolic status of the bacteria at the time of sampling (Neidhardt et al., 1990; Klappenbach et al., 2000). Not knowing the exact number of copies of $16 \mathrm{~S}$ rRNA operons in any given species at the time of sampling represents the main limitation to the absolute determination of bacterial numbers by real-time PCR based on $16 \mathrm{~S}$ rDNA. However, in a variety of complex environmental, industrial and health-related situations in which multi-species populations are sampled along with impurities, or where the bacteria are internalized within a matrix, other methodologies are likely to be far less sensitive or precise.

In this paper, we report the design of a universal probe and primers set which specifically detects $16 \mathrm{~S}$ rDNA of the Domain Bacteria and which is fully compatible with the TaqMan real-time PCR system. We have further characterized the use of this universal probe and primers set in enumerating bacteria with differing $t_{\mathrm{d}}$ and $\mathrm{rDNA}$ copy and applied this information to the determination of the anaerobic bacterial load in clinical samples derived from carious dentine where colony counting has, historically, been the preferred option.

\section{METHODS}

Bacterial strains and culture conditions. Escherichia coli strains JM109 (Yanisch-Perron et al., 1985), NM522 (Gough \& Murray, 1983) and XL-1 Blue (Stratagene) were available from previous studies. Staphylococcus aureus strains ATCC 12600, ATCC 9144, ATCC 12598, BM 10458 and BM 10143, Staphylococcus epidermidis strains ATCC 35983 and ATCC 14990, Staphylococcus haemolyticus ATCC 29970 and Staphylococcus haemolyticus (infiltrative keratitis isolate), Staphylococcus schleiferi ATCC 43808, Pseudomonas aeruginosa strains ATCC 19660, ATCC 15442, 6294 and 6206, Pseudomonas fluorescens (infiltrative keratitis isolate), Pseudomonas putida (lens saline isolate), Pseudomonas stutzeri (infiltrate isolate), Pseudomonas alcaligenes (laboratory isolate), Pseudomonas sp. and Serratia marcescens ATCC 274 were kindly provided by Dr Mark Willcox, Co-operative Research Centre for Eye Research and Technology, University of New South Wales, Australia. All Escherichia, Staphylococcus, Pseudomonas and Serratia species were grown in Luria-Burtani (LB) broth (Miller, 1972) at $37^{\circ} \mathrm{C}$ in a shaking incubator. Streptococcus mutans LT11 (Tao et al., 1993) and Streptococcus sanguinis ATCC 10556 (obtained from the American Type Culture Collection, Manassas, VA, USA) were grown at $37^{\circ} \mathrm{C}$ in Brain Heart Infusion broth (Oxoid) under $95 \% \mathrm{~N}_{2}$ and $5 \% \mathrm{CO}_{2}(\mathrm{v} / \mathrm{v})$; Fusobacterium nucleatum ATCC 25586, Fusobacterium necrophorum ATCC 25286, Actinomyces israelii ATCC 12102 and Actinomyces naeslundii ATCC 12104 were obtained from the American Type Culture Collection and grown at $37^{\circ} \mathrm{C}$ in Brain Heart Infusion broth in an anaerobic chamber $\left(85 \% \mathrm{~N}_{2}, 5 \% \mathrm{CO}_{2}, 10 \% \mathrm{H}_{2}\right.$, by vol.). Porphyromonas gingivalis ATCC 33277, Prevotella melaninogenica ATCC 25845, Peptostreptococcus micros ATCC 33270 and Peptostreptococcus anaerobius ATCC 27337 were obtained from the American Type Culture Collection and grown at $37^{\circ} \mathrm{C}$ in an anaerobic chamber in CDC broth $[1 \%, \mathrm{w} / \mathrm{v}$, trypticase peptone and $1 \%, \mathrm{w} / \mathrm{v}$, trypticase soy broth (Difco), $1 \%, \mathrm{w} / \mathrm{v}$, yeast extract (Oxoid), $5 \mathrm{mg} \mathrm{NaCl} \mathrm{ml}{ }^{-1}, 400 \mu \mathrm{g} \mathrm{L}$-cysteine $\mathrm{ml}^{-1}$ (Sigma)] containing $5 \mu \mathrm{g}$ haemin $\mathrm{ml}^{-1}$ (Sigma), $2 \mu \mathrm{g}$ menadione $\mathrm{ml}^{-1}$ (Sigma) and $2 \%(\mathrm{v} / \mathrm{v})$ horse serum (Commonwealth Serum Laboratories). Porphyromonas endodontalis ATCC 35406, obtained from the American Type Culture Collection, was also grown in an anaerobic chamber according to the method of Zerr et al. (1998). Lactobacillus acidophilus ATCC 4356 and Lactobacillus rhamnosus ATCC 7469 from the Institute of Dental Research Culture Collection (Westmead Centre for Oral Health, Westmead, NSW 2145, Australia) were grown at $37^{\circ} \mathrm{C}$ in MRS broth (Oxoid) under $95 \% \mathrm{~N}_{2}$ and $5 \% \mathrm{CO}_{2}$ ( $\mathrm{v} / \mathrm{v})$.

Source of carious dentine. Twenty carious teeth were obtained with informed consent from randomly selected patients who presented with pain and requested extraction to relieve their symptoms. Patients were excluded from the study if they reported a history of significant medical disease or antimicrobial therapy within the previous four months. Unrestored teeth with coronal enamel and dentine caries were selected for inclusion in the study on the basis of clinical diagnostic tests which indicated that they were vital, with clinical symptoms of reversible pulpitis (pain and heightened sensitivity to hot and cold stimuli). The study was approved by the Central Sydney Area Health Service Ethics Review Committee, Sydney, Australia (ref. no. 6/96). 
Immediately after extraction, each tooth was placed in a container of reduced transport fluid (RTF; Syed \& Loesche, 1972) and transferred to an anaerobic chamber at $37^{\circ} \mathrm{C}$ containing $85 \% \quad \mathrm{~N}_{2}, 5 \% \quad \mathrm{CO}_{2}$ and $10 \% \mathrm{H}_{2}$ (by vol.). Superficial plaque and debris overlying the carious lesion were removed and the surface rinsed several times with RTF. Using sterile sharp excavators, all the softened and carious dentine was collected as small fragments from each tooth. Sampling was completed within 20 min of tooth extraction.

Determination of c.f.u. in carious dentine. The carious dentine extracted from each tooth was individually weighed and a standard suspension of $10 \mathrm{mg}$ wet wt dentine $(\mathrm{ml}$ $\mathrm{RTF})^{-1}$ was prepared at $37^{\circ} \mathrm{C}$ in an anaerobic chamber (see above). The dentine fragments were homogeneously dispersed in RTF by first vortexing for $20 \mathrm{~s}$ and then homogenizing by hand in a $2 \mathrm{ml}$ glass homogenizer for $30 \mathrm{~s}$. Samples $(100 \mu \mathrm{l})$ of $10^{-3}-10^{-6}$ serial dilutions of these suspensions were prepared in RTF and plated in duplicate onto Trypticase Soy agar (Oxoid) containing $2 \mu \mathrm{g}$ menadione $\mathrm{ml}^{-1}, 5 \mu \mathrm{g}$ haemin $\mathrm{ml}^{-1}$, $400 \mu \mathrm{g} \mathrm{L}$-cysteine $\mathrm{ml}^{-1}$ (Sigma) and $5 \%(\mathrm{v} / \mathrm{v})$ horse blood (Amyl Media) (US Department of Health and Human Services - Centres for Disease Control, 1982). The plates were incubated at $37{ }^{\circ} \mathrm{C}$ in an anaerobic chamber containing $85 \% \mathrm{~N}_{2}$, $5 \% \mathrm{CO}_{2}$ and $10 \% \mathrm{H}_{2}$ (by vol.) for $14 \mathrm{~d}$ and the number of c.f.u. counted to determine the total microbial load (mg wet wt dentine $)^{-1}$. The unused dispersed carious dentine samples were frozen at $-80^{\circ} \mathrm{C}$.

Determination of viable bacteria from in vitro cultures. Viable cell counts of cultures of Escherichia coli, Pseudomonas aeruginosa and Staphylococcus aureus were determined by plating $100 \mu \mathrm{l}$ of a $10^{-6}$ dilution of the appropriate culture grown in LB broth on LB agar plates and counting the colonies after aerobic incubation at $37^{\circ} \mathrm{C}$ for $24 \mathrm{~h}$.

Extraction of DNA from bacterial cultures. DNA was isolated from individual bacterial species either by using the QIAamp DNA Mini Kit (Qiagen), according to the manufacturer's instructions, or by using a freeze-boil method. In the latter instance, bacterial cells from a $250 \mu \mathrm{l}$ aliquot of culture were obtained by centrifugation $\left(14000 \mathrm{~g}, 2 \mathrm{~min}, 18-20^{\circ} \mathrm{C}\right)$ and resuspended in $45 \mu \mathrm{l} 10 \mathrm{mM}$ phosphate buffer, $\mathrm{pH} 6 \cdot 7$, prior to freezing at $-20^{\circ} \mathrm{C}$. The frozen cells were then heated in a boiling water bath for $10 \mathrm{~min}$.

Extraction of anaerobic bacterial DNA from carious dentine. Frozen suspensions of homogenized carious dentine were thawed on ice and $80 \mu \mathrm{l}$ samples removed and combined with $100 \mu \mathrm{l}$ ATL buffer (Qiagen) and $400 \mu \mathrm{g}$ proteinase K (Qiagen). The samples were vortexed for $10 \mathrm{~s}$ and then incubated at $56{ }^{\circ} \mathrm{C}$ for $40 \mathrm{~min}$ with periodic vortexing for $10 \mathrm{~s}$ every $10 \mathrm{~min}$ to allow complete lysis of the cells. Following the addition of $200 \mu \mathrm{g}$ RNase (Sigma), the samples were incubated for a further 10 min at $37^{\circ} \mathrm{C}$. DNA free of contaminating RNA was then purified using the QIAamp DNA Mini Kit, according to the manufacturer's instructions.

Sources of other bacterial DNA. DNA from Legionella pneumophila serogroup 4 ATCC 33156, serogroup 5 ATCC 33216, serogroup 6 ATCC 33215, serogroup 1 Knoxville-1 ATCC 33153 and Philadelphia-1, as well as Legionella anisa, Legionella bozemanii (now Fluoribacter bozemanae) serogroup 2, Legionella londiniensis, Legionella (now Tatlockia) maceachernii and Legionella waltersii was kindly provided by Mr Rodney Ratcliff, Infectious Diseases Laboratories, Institute of Medical and Veterinary Science, SA, Australia. DNA from Mycobacterium tuberculosis H37RV was kindly provided by Mr Greg James, Microbiology Laboratory, Westmead Hospital, NSW, Australia.
DNA sequence analysis and design of the universal primers and probe. The designed probe and primers set were based on regions of identity within $16 \mathrm{~S}$ rDNA following the alignment of sequences from most of the groups of bacteria outlined in Bergey's Manual of Determinative Bacteriology (Holt et al., 1994). The $16 \mathrm{~S}$ rDNA sequences (GenBank accession no. in parentheses) from Bacteroides forsythus (AB035460), Porphyromonas gingivalis (POYRR16SC), Prevotella melaninogenica (PVORR16SF), 'Cytophaga baltica' (CBA5972), Campylobacter jejuni (CAJRRDAD), Helicobacter pylori (HPU00679), Treponema denticola (AF139203), Treponema pallidum (TRPRG16S), Leptothrix mobilis (LM16SRR), Thiomicrospira denitrificans (TDE243144), Neisseria meningitidis (AF059671), Actinobacillus (now Haemophilus) actinomycetemcomitans (ACNRRNAJ), Haemophilus influenzae (HIDNA5483), Escherichia coli (ECAT1177T), Salmonella typhi (STRNA16), Vibrio cholerae (VC16SRRNA), Coxiella burnetii (D89791), Legionella pneumophila (LP16SRNA), Pseudomonas aeruginosa (PARN16S), Caulobacter vibrioides (CVI009957), Rhodospirillum rubrum (RR16S107R), Nitrobacter winogradskyi (NIT16SRA), Wolbachia sp. (WSP010275), Myxococcus xanthus (MXA233930), Corynebacterium diphtheriae (CD16SRDNA), Mycobacterium tuberculosis (MTRRNOP), Streptomyces coelicolor (SC16SRNA), Actinomyces odontolyticus (AO16SRD), Bacillus subtilis (AB016721), Staphylococcus aureus (SA16SRRN), Listeria monocytogenes (S55472), Enterococcus faecalis (AB012212), Lactobacillus acidophilus (LBARR16SAZ), Streptococcus mutans (SM16SRNA), Clostridium botulinum (CBA16S), Peptostreptococcus (now Micromonas) micros (PEP16SRR8), Veillonella dispar (VDRRNA16S), Fusobacterium nucleatum (X55401), Chlamydia trachomatis (D89067) and Mycoplasma pneumoniae (AF132741) were aligned using the GCG program PILEUP (Wisconsin Package Version 8, 1994) accessed through the Australian National Genomic Information Service (ANGIS, http://www.angis.org.au).

The Primer Express Software provided by Applied Biosystems was of limited value in determining a universal probe and primers set as the primary selection criterion of the software is the length of the amplicon $(50-150 \mathrm{bp})$. The use of this software resulted in a series of best fit suggestions for the universal probe and primers set, leading to unsatisfactory sequence homology for many of the bacterial genera. As a result, the regions of identity within the $16 \mathrm{~S} \mathrm{rDNA}$ had to be assessed manually, with the Primer Express Software being limited to checking for primer-dimer or internal hairpin configurations, melting temperature $\left(T_{\mathrm{m}}\right)$ and percentage $\mathrm{G}+\mathrm{C}$ values within possible primer/probe sets. The final chosen set, including the forward primer, 5'-TCCTACGGGAGGCAGCAGT-3 $\left(T_{m}, 59 \cdot 4^{\circ} \mathrm{C}\right)$, the reverse primer, 5'-GGACTACCAGGGTATCTAATCCTGTT-3' $\left(T_{\mathrm{m}}, 58 \cdot 1^{\circ} \mathrm{C}\right)$ and the probe, (6-FAM)-5'-CGTATTACCGCGGCTGCTGGCAC$3^{\prime}$-(TAMRA) $\left(T_{m}, 69.9^{\circ} \mathrm{C}\right)$, complied with six of the eight guidelines set by Applied Biosystems for the design of primers and probes. These included $T_{m}$ of the DNA being between 58 and $60{ }^{\circ} \mathrm{C}$ for the primers and 68 and $70{ }^{\circ} \mathrm{C}$ for the probe; the $\mathrm{G}+\mathrm{C}$ content being between 30 and $80 \mathrm{~mol} \%$; no runs of more than three consecutive Gs in either the primers or the probe; no $\mathrm{G}$ on the $5^{\prime}$ end of the probe; and the probe selected from the strand with more Cs than Gs. The primers and probe set only deviated from the ideal in that the last 5 nt of the $3^{\prime}$ end of the forward primer contained more than two GCs and that the amplicon of $466 \mathrm{bp}$ (based on that generated between residues 331 and 797 on the Escherichia coli 16S rRNA gene) exceeded the 50-150 bp that was recommended.

The universal probe and primers were checked for possible 

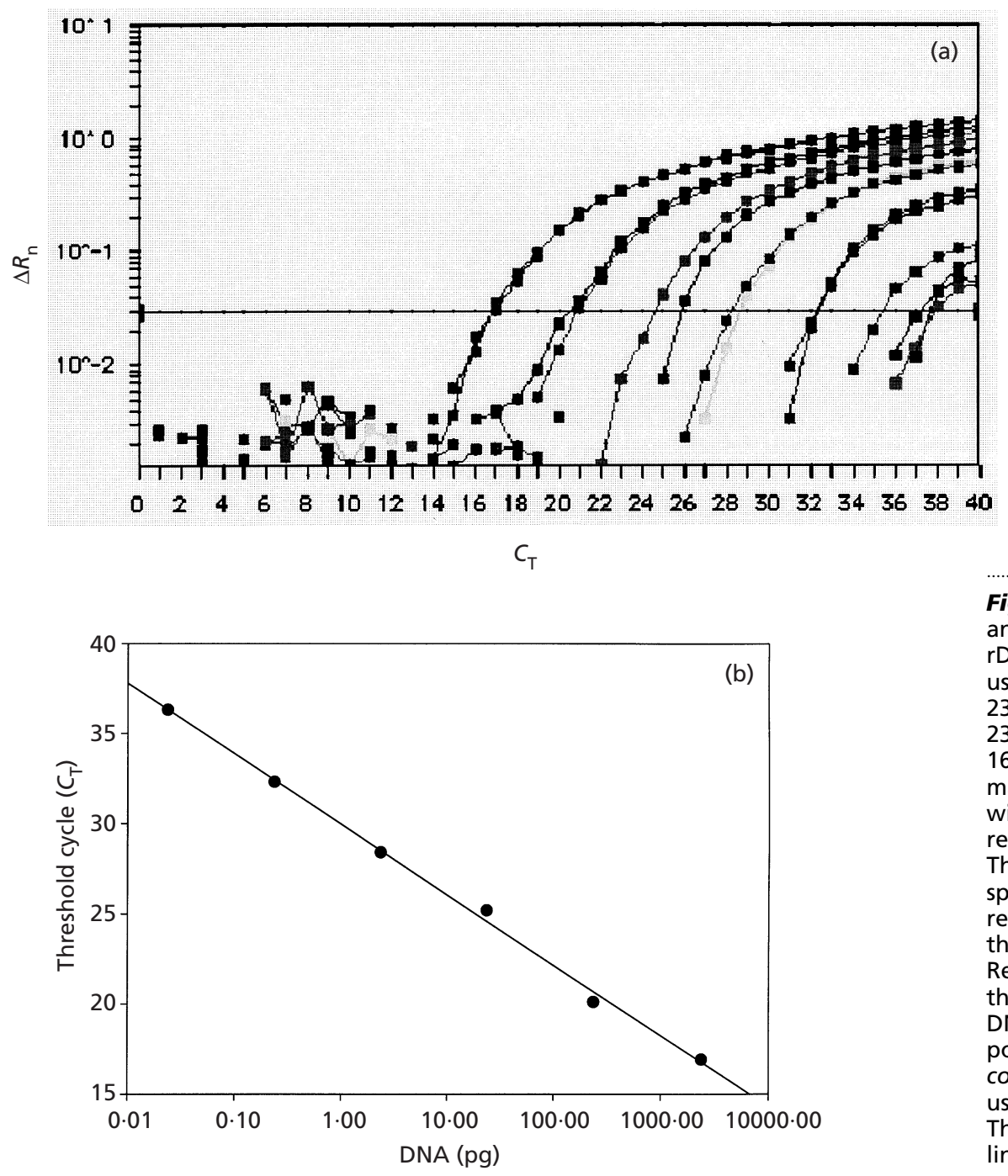

Fig. 1. (a) Sensitivity of the universal probe and primers set in detecting Escherichia coli rDNA. Purified Escherichia coli DNA was used as the template in quantities of $2380 \mathrm{pg}, 238 \mathrm{pg}, 23.8 \mathrm{pg}, 2.38 \mathrm{pg}, 238 \mathrm{fg}$ and $23.8 \mathrm{fg}$, representing $C_{T}$ values in the range 16.9-35.3 where the intercept of the magnitude of the fluorescence signal $\left(\Delta R_{\mathrm{n}}\right)$ with the horizontal threshold line in bold represents the $C_{\mathrm{T}}$ value for a given sample. The fluorescence signal at $C_{\mathrm{T}} 37.7$ corresponds to the no-template-control and represents bacterial DNA contamination in the commercially supplied reagents. (b) Relation between the threshold cycle and the apparent amount of Escherichia coli DNA using TaqMan real-time PCR. Each point represents an amount of Escherichia coli DNA corresponding to the $C_{\mathrm{T}}$ value using the universal probe and primers set. The correlation coefficient of the straight line, $R^{2}$, was 0.994 .

cross-hybridization with bacterial genes other than $16 \mathrm{~S}$ rDNA as well as genes from Eucarya and Archaea using the database similarity search program BLAST (Altschul et al., 1990) accessed through ANGIS. The BLAST search results showed only one significant hit - that of a specific breast cancer cell line (BT029) which was detected only by the reverse primer. However, the universal primers did not amplify the human DNA sample supplied by Applied Biosystems in their Betaactin Detection Kit probe set, thus confirming the specificity of the probe and primers set for the $16 \mathrm{~S}$ rDNA of the Domain Bacteria.

PCR conditions. Amplification and detection of DNA by realtime PCR were performed with the ABI-PRISM 7700 Sequence Detection System (Applied Biosystems) using optical grade 96well plates. Duplicate samples were routinely used for the determination of DNA by real-time PCR, except in the case of carious dentine where the DNA was amplified in triplicate and mean values calculated. The PCR reaction was performed in a total volume of $25 \mu \mathrm{l}$ using the TaqMan Universal PCR Master Mix (Applied Biosystems), containing $100 \mathrm{nM}$ of each of the universal forward and reverse primers and the fluorogenic probe, except for the determination of the predominantly anaerobic bacterial load in carious dentine where
$300 \mathrm{nM}$ of the forward and reverse primers and $175 \mathrm{nM}$ of the fluorogenic probe were used with the TaqMan PCR Core Reagents Kit. The reaction conditions for amplification of DNA were $50^{\circ} \mathrm{C}$ for $2 \mathrm{~min}, 95^{\circ} \mathrm{C}$ for $10 \mathrm{~min}$ and 40 cycles of $95^{\circ} \mathrm{C}$ for $15 \mathrm{~s}$ and $60^{\circ} \mathrm{C}$ for $1 \mathrm{~min}$. Data analysis made use of Sequence Detection Software version 1.6.3 supplied by Applied Biosystems.

DNA standards used for determining bacterial number by real-time PCR. Escherichia coli DNA was generally used as the standard for determining bacterial number by real-time PCR. However, to determine the effect of variations in rDNA copy number as well as the multiplying effect of the $t_{\mathrm{d}}$ on the calculation of bacterial number, DNA standards were also prepared from two rapidly growing aerobic bacteria, Staphylococcus aureus and Pseudomonas aeruginosa, with $t_{\mathrm{d}}$ in vitro in the order of 20-50 min and two slow-growing obligate oral anaerobes, Prevotella melaninogenica and Porphyromonas endodontalis, with $t_{\mathrm{d}}$ in vitro in the order of 5-15 h. Standard graphs were always prepared from data accumulated at the same time as the test samples to act as internal controls.

Relative estimation of bacteria in an artificial in vitro mixture and in carious dentine. To determine the validity of using the 
Table 1. Representative bacterial species detected by real-time PCR using the universal probe and primers set

\begin{tabular}{|c|c|}
\hline Bacterial species* & $\mathrm{C}_{\mathrm{T}}^{\dagger}$ \\
\hline \multicolumn{2}{|l|}{ Gram-negative aerobic bacteria } \\
\hline Pseudomonas aeruginosa ATCC 19660 & $18 \cdot 14$ \\
\hline Pseudomonas aeruginosa ATCC 15442 & $18 \cdot 46$ \\
\hline Pseudomonas aeruginosa 6294 & $18 \cdot 26$ \\
\hline Pseudomonas aeruginosa 6206 & $19 \cdot 67$ \\
\hline Pseudomonas fluorescens & $19 \cdot 19$ \\
\hline Pseudomonas putida & $22 \cdot 35$ \\
\hline Pseudomonas stutzeri & $18 \cdot 87$ \\
\hline Pseudomonas alcaligenes & $19 \cdot 33$ \\
\hline Pseudomonas sp. & $19 \cdot 52$ \\
\hline Legionella pneumophila Knoxville-1 ATCC 33153 & $21 \cdot 93$ \\
\hline Legionella pneumophila serogroup 4 ATCC 33156 & $21 \cdot 34$ \\
\hline Legionella pneumophila serogroup 5 ATCC 33216 & $\underline{20 \cdot 08}$ \\
\hline Legionella pneumophila serogroup 6 ATCC 33215 & $\overline{21 \cdot 19}$ \\
\hline Legionella pneumophila Philadelphia-1 ATCC 33152 & $25 \cdot 18$ \\
\hline Legionella anisa & $24 \cdot 02$ \\
\hline $\begin{array}{l}\text { Legionella bozemanii serogroup } 2 \text { (now Fluoribacter } \\
\text { bozemanae) }\end{array}$ & $21 \cdot 46$ \\
\hline Legionella londiniensis & $20 \cdot 50$ \\
\hline Legionella (now Tatlockia) maceachernii & $22 \cdot 97$ \\
\hline Legionella waltersii & $21 \cdot 96$ \\
\hline \multicolumn{2}{|l|}{ Gram-negative facultative anaerobic bacteria } \\
\hline Escherichia coli JM109 & $19 \cdot 86$ \\
\hline Escherichia coli NM522 & $28 \cdot 22$ \\
\hline Escherichia coli XL-1 Blue & $26 \cdot 95$ \\
\hline Serratia marcescens ATCC 274 & $20 \cdot 96$ \\
\hline \multicolumn{2}{|l|}{ Gram-negative anaerobic bacteria } \\
\hline Porphyromonas gingivalis ATCC 33277 & $23 \cdot 50$ \\
\hline Porphyromonas endodontalis ATCC 35406 & $22 \cdot 05$ \\
\hline Prevotella melaninogenica ATCC 25845 & $20 \cdot 48$ \\
\hline Fusobacterium necrophorum ATCC 252 & $23 \cdot 15$ \\
\hline Fusobacterium nucleatum ATCC 25586 & $21 \cdot 05$ \\
\hline \multicolumn{2}{|l|}{ Gram-positive bacteria } \\
\hline Staphylococcus aureus ATCC 12600 & $16 \cdot 15$ \\
\hline Staphylococcus aureus ATCC 9144 & $29 \cdot 57$ \\
\hline Staphylococcus aureus ATCC 12598 & $27 \cdot 41$ \\
\hline Staphylococcus aureus BM 10458 & $\underline{26 \cdot 32}$ \\
\hline Staphylococcus aureus BM 10143 & $27 \cdot 20$ \\
\hline Staphylococcus epidermidis ATCC 35983 & $17 \cdot 88$ \\
\hline Staphylococcus epidermidis ATCC 14990 & $22 \cdot 27$ \\
\hline Staphylococcus haemolyticus ATCC 29970 & $21 \cdot 14$ \\
\hline Staphylococcus haemolyticus & $\underline{22 \cdot 28}$ \\
\hline Staphylococcus schleiferi ATCC 43808 & $22 \cdot 29$ \\
\hline Streptococcus sanguinis ATCC 10556 & $17 \cdot 05$ \\
\hline Streptococcus salivarius ATCC 25975 & $20 \cdot 27$ \\
\hline Streptococcus gordonii ATCC 10558 & $20 \cdot 03$ \\
\hline Streptococcus mutans LT11 & $18 \cdot 78$ \\
\hline Peptostreptococcus anaerobius ATCC 27337 & $22 \cdot 36$ \\
\hline $\begin{array}{l}\text { Peptostreptococcus (now Micromonas) micros ATCC } \\
33270\end{array}$ & $22 \cdot 83$ \\
\hline \multicolumn{2}{|l|}{ Gram-positive asporogenous bacteria } \\
\hline Lactobacillus acidophilus ATCC 4356 & $20 \cdot 73$ \\
\hline Lactobacillus rhamnosus ATCC 7469 & $24 \cdot 53$ \\
\hline
\end{tabular}

Table 1 (cont.)

\begin{tabular}{|lc|}
\hline Bacterial species* $^{*}$ & $\mathrm{C}_{\mathrm{T}} \dagger$ \\
\hline Actinomycetes & \\
Actinomyces naeslundii ATCC 12104 & $24 \cdot 32$ \\
Actinomyces israelii ATCC 12102 & $26 \cdot 38$ \\
Mycobacterium tuberculosis H37RV & $26 \cdot 00$ \\
\hline
\end{tabular}

*Groups of bacteria based on Bergey's Manual of Determinative Bacteriology (Holt et al., 1994).

† DNA was either extracted from equivalent volumes of cultured bacteria or obtained from independent sources and diluted to be within the range of the threshold cycle $\left(C_{T}\right)$ of the standard graph $\left(C_{T}\right.$ vs [Escherichia coli DNA]). The data are the means of duplicate determinations. Variation in duplicates was $\leqslant 3.7 \%$, except where underlined where the duplicates varied between $6 \cdot 0$ and $11 \cdot 8 \%$.

universal probe and primers set to estimate the total number of bacteria in a mixed culture, three bacteria, Escherichia coli, Pseudomonas aeruginosa and Staphylococcus aureus, were grown separately in vitro to late-exponential-early-stationary phase and equal volumes of the three cultures $(2 \mathrm{ml})$ mixed together. The number of Escherichia coli, Pseudomonas aeruginosa and Staphylococcus aureus c.f.u. at stationary phase was determined by serial dilution on agar plates and compared with the relative bacterial load determined by realtime PCR using the universal probe and primers set and Escherichia coli DNA as the standard.

The total number of c.f.u. obtained from carious dentine samples were determined by serial dilution on agar plates in an anaerobic chamber as described above and compared with the relative bacterial load determined by real-time PCR using the universal probe and primers set and Prevotella melaninogenica ATCC 25845 DNA as the standard.

\section{RESULTS AND DISCUSSION}

\section{Sensitivity of the universal probe and primers in detecting Escherichia coli rDNA}

TaqMan technology determines the PCR cycle at which the increase in fluorescence of the reporter dye reaches a threshold cycle $\left(C_{\mathrm{T}}\right)$ (Fig. 1a). $C_{\mathrm{T}}$ is proportional to the $\log$ of the amount of target DNA and hence the log of the number of bacteria in the sample, provided there is only one copy of the reported sequence within the genome. Our standard graph was based on Escherichia coli rDNA, where one Escherichia coli cell theoretically equates to the detection of $4.96 \mathrm{fg}$ DNA, provided the seven copies of rDNA in each copy of the chromosome (Farelly et al., 1995) are not taken into consideration (Fig. 1b). Using Escherichia coli as a standard, we consistently detected between $238 \mathrm{fg}$ (corresponding to 48 Escherichia coli cells) and 2.38 ng Escherichia coli DNA (corresponding to $4 \cdot 8 \times 10^{5}$ Escherichia coli cells). This we designated as the apparent amount of DNA and the apparent number of Escherichia coli cells. It should be noted that at extreme high and low $C_{\mathrm{T}}$ values, a two- 
fold error in the estimation of the relative amount of DNA can occur. $C_{\mathrm{T}}$ values below $0 \cdot 1 \mathrm{pg}$ and above 1000 pg DNA should therefore be avoided in calculating the amount of DNA in a sample, provided alternative dilutions are practical (Fig. 1b).

Detection in the apparent range of $4 \cdot 8-48$ cells was limited by contamination from bacterial DNA in the commercially supplied reagents. The degree of contamination varied with different kits of the TaqMan Universal PCR Master Mix and TaqMan PCR Core Reagents Kit. This contamination is thought to be present in either the enzyme preparation or the chemical reagents used for PCR (Bottger, 1990; Schmidt et al., 1991; Corless et al., 2000; Lyons et al., 2000), an observation verified in this current study by the presence of rDNA in reagent mixes and negative controls containing no added Escherichia coli DNA (Fig. 1a). To minimize this problem we tested different lot numbers of TaqMan Universal PCR Master Mix and TaqMan PCR Core Reagents Kit supplied by Applied Biosystems and purchased only those with minimum contaminating DNA. Although 40 cycles are theoretically available for the reaction, contamination of reagents manifest in the no-template-control restricted the sensitivity of the reaction to $C_{\mathrm{T}}$ values below 33-38 cycles, depending on the batches of reagents used.

\section{Broad-range detection of bacterial species by the universal probe and primers set}

To determine the ability of the universal probe and primers set to detect a broad range of bacteria, samples of DNA extracted from 49 different strains representing 34 different species from the major groups of bacteria listed in Bergey's Manual of Determinative Bacteriology (Holt et al. 1994), were subjected to real-time PCR using the probe and primers set. All of the selected species were detected within a $C_{\mathrm{T}}$ range of $17 \cdot 05-34 \cdot 00$ (Table 1). For each species there was little variance in the value of $2.00 \times 10^{2}$ (range $\left.1.98 \times 10^{2}-2.06 \times 10^{2}\right)$ Escherichia coli-equivalent bacteria (pg DNA) ${ }^{-1}$ when Escherichia coli DNA was used as a standard, indicating that the source of DNA was not influencing the level of detection and that the probe and primers set was equally efficient in detecting the DNA irrespective of the species from which it was extracted. Only in the case Micromonas (formerly Peptostreptococcus) micros was there a mismatch in identity between the probe and primers set and the $16 \mathrm{~S}$ rDNA. This constituted a single nucleotide deletion in the $16 \mathrm{~S}$ rDNA compared with the $5^{\prime}$ end of the forward primer. This sequence discrepancy was clearly tolerated during real-time PCR detection of Micromonas (formerly Peptostreptococcus) micros DNA (Table 1).

Although larger than the $150 \mathrm{bp}$ limit set in the Applied Biosystems protocol, our 466 bp amplicon was clearly uniformly successful in detecting a wide range of bacteria. Corless et al. (2000) have recently reported a universal probe and primers set as a tool for the rapid detection of bacteria by real-time PCR. However, our analysis of their forward and reverse primers and probe showed multiple mismatches with most of the dental pathogens, including Bacteroides forsythus, Porphyromonas gingivalis and Prevotella melaninogenica, and one or more mismatches with many other bacteria at the $5^{\prime}$ as well as the $3^{\prime}$ ends. Similarly, the universal probe and primers set described by Lyons et al. (2000) for the detection of total bacteria in dental plaque has one or two mismatches within the probe for the $16 \mathrm{~S}$ rDNA of Staphylococcus aureus, Campylobacter jejuni, Helicobacter pylori, Wolbachia sp., Micromonas (formerly Peptostreptococcus) micros, Fusobacterium nucleatum, Mycoplasma pneumoniae, Leptothrix mobilis and Thiomicrospira denitrificans, and their reverse primer has no corresponding $16 \mathrm{~S} \mathrm{rDNA}$ sequences in the databases for numerous Gram-positive and Gramnegative bacteria. Furthermore, their probe and primers set exceeds a number of the guidelines set by Applied Biosystems for TaqMan technology. Their probe was selected from the strand with more Gs than Cs, which could affect the amount of fluorescence measured. The $T_{\mathrm{m}}$ of 48.4 and $35.4{ }^{\circ} \mathrm{C}$ for their forward and reverse primers, respectively (calculated from their reported sequences using Primer Express Software), contrasts with the $58-60^{\circ} \mathrm{C}$ set by Applied Biosystems and necessitated the authors to use additional annealing steps at $52{ }^{\circ} \mathrm{C}$ for $1 \mathrm{~min}$ and $72{ }^{\circ} \mathrm{C}$ for 2 min to allow for the elongation of their longer amplicon $(727 \mathrm{bp})$. This extended the total reaction time by at least $70 \mathrm{~min}$ when using the ABI-PRISM 7700 Sequence Detection System for real-time PCR. The total time taken for quantification was further increased by the requirement for an initial PCR reaction.

\section{Effect of the source of standard DNA on the measurement of relative DNA concentration}

To confirm that a DNA standard other than that of Escherichia coli should result in a difference in the relative amount of DNA detected due to variations in rDNA copy number and the effect of the $t_{\mathrm{d}}$ on this number, the relative amounts of DNA from the rapidly growing aerobic bacteria Staphylococcus aureus, Escherichia coli and Pseudomonas aeruginosa were compared with the slow-growing obligate oral anaerobes Prevotella melaninogenica and Porphyromonas endodontalis. In each instance the relative amount of DNA was estimated by real-time PCR using each of the five DNAs as standards and compared with the amount of DNA determined at $A_{260}$ (set at $100 \%$ ). It would be expected that comparison of like DNA by real-time PCR with the known amount of added DNA would be approximately $100 \%$. In two instances this was not the case. For both Pseudomonas aeruginosa and Prevotella melaninogenica approximately twice the amount of DNA was detected. This was due in part to the fact that the relative amounts of DNA were calculated by Sequence Detection System version 1.6.3 software supplied by Applied Biosystems based upon the arbitrary placement of the horizontal threshold line used to 
Table 2. Effect of species-specific DNA standards on the relative estimation of DNA concentration using the universal probe and primers set for real-time PCR

\begin{tabular}{|c|c|c|c|c|c|c|}
\hline \multirow[t]{2}{*}{ Bacterium } & \multicolumn{6}{|c|}{ Relative amount of DNA $(\%)^{*}$} \\
\hline & $A_{260} \dagger$ & $\begin{array}{l}\text { Staphylococcus } \\
\text { aureus DNA } \\
\text { std }\end{array}$ & $\begin{array}{c}\text { Escherichia } \\
\text { coli DNA } \\
\text { std }\end{array}$ & $\begin{array}{l}\text { Pseudomonas } \\
\text { aeruginosa } \\
\text { DNA std }\end{array}$ & $\begin{array}{l}\text { Porphyromonas } \\
\text { endodontalis } \\
\text { DNA std }\end{array}$ & $\begin{array}{c}\text { Prevotella } \\
\text { melaninogenica } \\
\text { DNA std }\end{array}$ \\
\hline Staphylococcus aureus & 100 & 106 & 145 & 294 & 1231 & 2278 \\
\hline Escherichia coli & 100 & 46 & 96 & 139 & 550 & 1304 \\
\hline Pseudomonas aeruginosa & 100 & 48 & 96 & 139 & 456 & 669 \\
\hline Porphyromonas endodontalis & 100 & 8 & 17 & $\underline{9}$ & 108 & 201 \\
\hline Prevotella melaninogenica & 100 & 5 & $\underline{11}$ & 10 & 68 & 122 \\
\hline
\end{tabular}

*The species-specific standard DNA graphs $\left(C_{\mathrm{T}}\right.$ vs $[\mathrm{DNA}]$; cf. Fig. 1) were generated from Escherichia coli DNA within the range $238 \mathrm{fg}-2.38 \mathrm{ng}$, from Pseudomonas aeruginosa DNA within the range $25 \mathrm{fg}-2.5 \mathrm{ng}$, from Staphylococcus aureus DNA within the range $27 \cdot 5 \mathrm{fg}-2 \cdot 75 \mathrm{ng}$, from Prevotella melaninogenica DNA within the range $1.12 \mathrm{pg}-112 \mathrm{ng}$ and from Porphyromonas endodontalis DNA within the range $240 \mathrm{fg}-24 \mathrm{ng}$. The mean values of duplicate determinations are shown. Variation between duplicates was $\leqslant 2 \cdot 7 \%$, except where underlined where the values for the Escherichia coli, Prevotella melaninogenica and Pseudomonas aeruginosa DNA standards varied by $4 \cdot 8,10 \cdot 5$ and $15 \cdot 9 \%$ respectively.

† The concentration of DNA was determined spectrophotometrically and normalized to $100 \%$ prior to diluting in the range of 100 - to 1000-fold for determination by real-time PCR.

determine the $C_{\mathrm{T}}$ (cf. Fig. 1a). The horizontal threshold line was therefore adjusted to bring these two values as close to $100 \%$ as possible and the relative amount of DNA recalculated (Table 2).

As expected, variation in the relative amount of DNA was observed when the standard DNA differed from that of the species being evaluated (Table 2). However, significant error ( $>$ threefold) was only observed when the fast-growing aerobic bacteria were compared with the DNA standards of the slow-growing obligate anaerobes (over estimation) or conversely, when the obligate anaerobes were compared to the DNA of the fastgrowing aerobes (under estimation) (Table 2).

The data in Table 2 allowed an estimation of the ratio of the number of copies of the $16 \mathrm{~S}$ rRNA operons in the different species. A mean ratio of $20: 10: 9: 1: 1$ (to the nearest integer) for the copy numbers in Staphylococcus aureus, Escherichia coli, Pseudomonas aeruginosa, Porphyromonas endodontalis and Prevotella melaninogenica, respectively, fitted the data. This implied that the fast-growing aerobes, Staphylococcus aureus, Escherichia coli and Pseudomonas aeruginosa possessed approximately twice the known chromosomal complement of $16 \mathrm{~S}$ rRNA operons. The data also predicted that the obligate anaerobes possess only one or two $16 \mathrm{~S}$ rRNA operons per chromosome. The exact copy numbers are currently unknown.

These results demonstrate that failure to compare DNA from similar groups of bacteria possessing similar growth rates readily leads to an under or over estimation of the amount of DNA by one order of magnitude. Our analyses, however, show that if the ratio of the estimated amount of DNA measured against a rapidly growing bacterium, such as Staphylococcus aureus, to that measured against a slow-growing bacterium, such as Prevotella melaninogenica, is $<1 \cdot 0$, then the number of bacteria in the sample should be estimated using the DNA extracted from the fast-growing bacterium. If the ratio is $>1 \cdot 0$, the alternative standard DNA from the slow-growing bacterium should be used. In practice, this may simply require reference to a standard curve where the DNA is derived from a bacterium considered to represent the predominant species in the sample. Others, however, have come to different conclusions. For instance, Lyons et al. (2000) found no difference in the number of rDNAs per bacterial cell for Haemophilus (formerly Actinobacillus) actinomycetemcomitans, Porphyromonas gingivalis, Escherichia coli and group $\mathrm{G}$ streptococci and therefore assumed that the mean number of $16 \mathrm{~S}$ rDNA operons in each bacterial cell was similar in all dental plaque samples. Thus, they made no attempt to compensate for differences in $16 \mathrm{~S}$ rDNA copy number.

\section{Comparison of viable cell numbers and the relative estimation of bacteria in an artificial in vitro mixture using real-time PCR}

To determine the validity of using the universal probe and primers set to estimate the total number of bacteria in a mixed culture, Escherichia coli, Pseudomonas aeruginosa and Staphylococcus aureus were grown separately and equal volumes of the three cultures mixed together. The number of bacteria was similar irrespective of whether the estimation was made using realtime PCR or colony counting (Table 3), despite the fact that the number of copies of the $16 \mathrm{~S}$ rRNA operons in a single chromosome of Escherichia coli is seven while 
Table 3. Enumeration of bacterial cell numbers by viable cell count and real-time PCR

\begin{tabular}{|lcc|}
\hline Bacterial culture & $\begin{array}{c}\text { Viable cell count } \\
{\left[\text { cells }(\mathbf{m l} \text { culture })^{-1}\right]^{*}}\end{array}$ & $\begin{array}{c}\text { Relative estimation of cell numbers } \\
\text { by real-time PCR [cells (ml culture })^{-1} \text { ] }\end{array}$ \\
\hline Escherichia coli & $6 \cdot 5 \times 10^{8}$ & $6 \cdot 7 \times 10^{8}$ \\
Pseudomonas aeruginosa & $3 \cdot 3 \times 10^{9}$ & $4 \cdot 2 \times 10^{9}$ \\
Staphylococcus aureus & $1 \cdot 3 \times 10^{9}$ & $2.5 \times 10^{9}$ \\
Mixed culture $\neq$ & $1 \cdot 4 \times 10^{9} \mathbb{S}$ & $\underline{1.3 \times 10^{9}}$ \\
\hline
\end{tabular}

$*$ The data are the means of duplicate determinations. Variation between duplicates was $\leqslant 5 \cdot 2 \%$.

† Based on a standard graph generated by Escherichia coli DNA within the range $238 \mathrm{fg}-2.38 \mathrm{ng}$. The mean of duplicate determinations for each of two dilutions of DNA are shown. Variation between duplicates did not exceed $3.0 \%$, except for one dilution where the variation was $8 \cdot 8 \%$ (underlined).

‡The mixed culture consisted of equal volumes of Escherichia coli, Psendomonas aeruginosa and Staphylococcus aureus cultures.

\$Estimated from the viable cell numbers measured in each of the three cultures.

Table 4. Real-time PCR estimation of anaerobic bacteria in carious dentine compared with the total viable anaerobic load

The method of DNA extraction lyses anaerobic Gram-negative and Gram-positive bacteria, but not facultative Gram-positive bacteria.

\begin{tabular}{|cccc|}
\hline Sample & $\begin{array}{c}\text { Estimation of Gram-negative bacteria } \\
\left.\text { by real-time PCR [cells }(\text { mg dentine })^{-1}\right]^{*}\end{array}$ & $\begin{array}{c}\text { Viable c.f.u. [c.f.u. } \\
\left.(\text { mg dentine })^{-1}\right] \dagger\end{array}$ & $\begin{array}{c}\text { Ratio [cells } \\
(\text { c.f.u. })^{-1} \text { ] }\end{array}$ \\
\hline 1 & $3 \cdot 4 \times 10^{8}$ & $9 \cdot 0 \times 10^{6}$ & 38 \\
2 & $\frac{4 \cdot 5 \times 10^{8}}{4 \cdot 8 \times 10^{8}}$ & $5 \cdot 5 \times 10^{6}$ & 82 \\
3 & $1 \cdot 3 \times 10^{8}$ & $9 \cdot 8 \times 10^{6}$ & 49 \\
4 & $3 \cdot 8 \times 10^{8}$ & $4 \cdot 8 \times 10^{6}$ & 27 \\
5 & $5 \cdot 5 \times 10^{8}$ & $1 \cdot 2 \times 10^{7}$ & 32 \\
6 & $1 \cdot 4 \times 10^{8}$ & $1 \cdot 2 \times 10^{7}$ & 46 \\
7 & $1 \cdot 1 \times 10^{8}$ & $6 \cdot 9 \times 10^{6}$ & 21 \\
8 & $1 \cdot 9 \times 10^{8}$ & $2 \cdot 0 \times 10^{6}$ & 55 \\
9 & $3 \cdot 7 \times 10^{8}$ & $1 \cdot 5 \times 10^{7}$ & 13 \\
10 & $1 \cdot 4 \times 10^{8}$ & $2 \cdot 2 \times 10^{7}$ & 17 \\
11 & $3 \cdot 6 \times 10^{8}$ & $3 \cdot 1 \times 10^{6}$ & 45 \\
12 & $1 \cdot 5 \times 10^{8}$ & $5 \cdot 9 \times 10^{6}$ & 61 \\
13 & $1 \cdot 1 \times 10^{9}$ & $2 \cdot 2 \times 10^{6}$ & 68 \\
14 & $2 \cdot 6 \times 10^{8}$ & $1 \cdot 2 \times 10^{7}$ & 92 \\
15 & $\underline{2 \cdot 5 \times 10^{8}}$ & $1 \cdot 4 \times 10^{7}$ & 19 \\
16 & $2 \cdot 8 \times 10^{8}$ & $1 \cdot 5 \times 10^{7}$ & 17 \\
17 & $6 \cdot 5 \times 10^{8}$ & $8 \cdot 2 \times 10^{6}$ & 34 \\
18 & $2 \cdot 5 \times 10^{8}$ & $1 \cdot 6 \times 10^{7}$ & 41 \\
19 & $6 \cdot 7 \times 10^{8}$ & $5 \cdot 6 \times 10^{6}$ & 45 \\
20 & $1 \cdot 7 \times 10^{7}$ & 18 \\
\hline
\end{tabular}

*Based on a standard graph generated by Prevotella melaninogenica DNA within the range $82.9 \mathrm{fg}-8.29 \mathrm{ng}$, where $2.36 \mathrm{fg}$ Prevotella melaninogenica DNA represents one cell. The data are the means of triplicate determinations. The standard deviation of the means varied by $\leqslant 1.0 \%$, except where underlined where the variation was in the range $1 \cdot 7-4 \cdot 4 \%$.

$\dagger$ The data are the means of duplicate determinations. Variation between duplicates was $\leqslant 10 \cdot 0 \%$.

$\ddagger$ The ratio represents the $n$-fold increase in anaerobic bacteria detected by real-time PCR over the total colony count which includes facultative Gram-positive bacteria.

that in Pseudomonas aeruginosa is four (Farelly et al., 1995) and Staphylococcus aureus is nine (Gurtler \& Stanisich, 1996), and the further expectation that Pseudo- monas aeruginosa would be underestimated (as was apparently the case) and Staphylococcus aureus overestimated against the Escherichia coli standard DNA. 


\section{Comparison of the number of anaerobic bacteria in carious dentine by real-time PCR with the total anaerobic colony count}

Determination of bacterial numbers in carious dentine has routinely utilized culture-based techniques. The presence of bacteria adhering to the dentinal matrix or internalized as co-adhering colonies within the dentinal tubules precludes enumeration by microscopic or fluorescence techniques. While colony counting has been the method of choice, this is clearly limiting due to the complex nature of the bacterial flora and their fastidious nutritional requirements. Furthermore, a colony on a plate can be formed by more than one proximal cell, as is the case, for instance, with chains of streptococcal cells. The value of using the universal probe and primers set in estimating the anaerobic bacterial load in carious dentine was therefore determined in 20 clinical samples using Prevotella melaninogenica ATCC 25845 DNA from anaerobically grown cells as the standard. Comparison was made with the total anaerobic colony count for each of the samples. The mean number of anaerobic bacteria determined by real-time PCR was $3.6 \times 10^{8}(\mathrm{mg}$ dentine $)^{-1} \quad$ range $1.1 \times 10^{8}-1 \cdot 1 \times 10^{9} \quad(\mathrm{mg} \text { dentine })^{-1}$, while that for the total viable cell count was $1 \cdot 1 \times 10^{7}$ $(\mathrm{mg} \text { dentine })^{-1}\left[\right.$ range $\left.2 \cdot 0 \times 10^{6}-3 \cdot 7 \times 10^{7}(\mathrm{mg} \text { dentine })^{-1}\right]$ (Table 4).

It should be noted that the ATL buffer/proteinase $\mathrm{K}$ procedure used in this study not only extracted DNA from Gram-negative anaerobic bacteria but also partially from Gram-positive anaerobic bacteria (data not shown). This is in line with the finding that the cell-wall integrity of Gram-positive anaerobes is compromised when the bacteria are exposed to oxygen (Johnson et al., 1995). Other microaerophilic or facultative Grampositive bacteria, including streptococci, lactobacilli and Actinomyces, were not lysed by this procedure (data not shown). Consequently, the finding that the anaerobic bacterial load in samples of carious dentine was 40-fold greater on average than the total anaerobic colony count, which also includes 5-10\% Gram-positive facultative bacteria (Massey et al., 1993) that are not lysed by the technique employed, clearly demonstrates the value of our universal probe and primers set in enumerating bacterial numbers by real-time PCR in the presence of a contaminating matrix. Furthermore, the real-time PCR results could be obtained in 6-8 h from patient sampling compared with $14 \mathrm{~d}$ for the colony counts. By using species-specific probes with real-time PCR, it will also be possible to rapidly enumerate the numbers of different types of bacteria within these samples and compare them to the cultivable bacteria grown on selective media.

In conclusion, the universal probe and primers set that we have developed for the TaqMan system enables the sensitive detection of numerous bacterial species and strains belonging to the major groups of bacteria defined in Bergey's Manual of Determinative Bacteriology (Holt et al., 1994), without cross-detection of DNA from Eucarya or Archaea. Detection was achieved in mini- mum time and with no additional handling of the PCR product, thereby reducing the chances of contamination. We therefore believe that our designed universal probe and primers set should universally estimate total bacteria by real-time PCR in the shortest possible time. The greatest potential of our probe and primers set lies in its ability to detect bacteria from environmental samples which are difficult to cultivate and that would in all practicality remain undetected or underestimated by viable culture count methods or, alternatively, bacteria that are in an aggregated or coaggregated state or contained within matrix material, such as the carious dentine samples examined in this study, where fluorescent detection and/or microscopic enumeration are also impractical. In addition, the application of this universal probe and primers set could enable rapid differentiation of bacterial from viral infections within the limited time constraints sometimes experienced in life-threatening clinical situations.

\section{ACKNOWLEDGEMENTS}

This work was supported by a grant from the Dental Board of New South Wales, Australia. F.E.M. is the recipient of an Australian National Health and Medical Research Council Dental Postgraduate Research Scholarship (No. 978005).

\section{REFERENCES}

Altschul, S. F., Gish, W., Miller, W., Myers, E. W. \& Lipman, D. J. (1990). Basic local alignment search tool. J Mol Biol 215, 403-410.

Amann, R. I., Ludwig, W. \& Schleifer, K.-H. (1995). Phylogenetic identification and in situ detection of individual microbial cells without cultivation. Microbiol Rev 59, 143-169.

Attfield, P., Gunasekera, T., Boyd, A., Deere, D. \& Veal, D. (1999). Applications of flow cytometry to microbiology of food and beverage industries. Australas Biotechnol 9, 159-166.

Blok, H. J., Gohlke, A. M. \& Akkermans, A. D. (1997). Quantitative analysis of $16 \mathrm{~S}$ rDNA using competitive PCR and the QPCR system 5000. Biotechniques 22, 700-704.

Bottger, E. C. (1990). Frequent contamination of Taq polymerase with DNA. Clin Chem 36, 1258-1259.

Corless, C. E., Guiver, M., Borrow, R., Edwards-Jones, V., Kaczmarski, E. B. \& Fox, A. J. (2000). Contamination and sensitivity issues with a real-time universal $16 \mathrm{~S}$ rRNA PCR. J Clin Microbiol 38, 1747-1752.

Dymock, D., Weightman, A. J., Scully, C. \& Wade, W. G. (1996). Molecular analysis of microflora associated with dentoalveolar abscesses. J Clin Microbiol 34, 537-542.

Farelly, V., Rainley, F. A. \& Stackebrandt, E. (1995). Effect of genome size and $r r n$ gene copy number on PCR amplification of $16 \mathrm{~S}$ rRNA genes from a mixture of bacterial species. Appl Environ Microbiol 61, 2798-2801.

Gough, J. \& Murray, N. (1983). Sequence diversity among related genes for recognition of specific targets in DNA molecules. $J \mathrm{Mol}$ Biol 166, 1-19.

Greisen, K., Loeffelholz, M., Purohit, A. \& Leong, D. (1994). PCR primers and probes for the $16 \mathrm{~S}$ rRNA gene of most species of pathogenic bacteria, including bacteria found in cerebrospinal fluid. J Clin Microbiol 32, 335-351.

Gurtler, V. \& Stanisich, V. A. (1996). New approaches to typing 
and identification of bacteria using 16S-23S rDNA spacer region. Microbiology 142, 3-16.

Heid, C. A., Stevens, J., Livak, K. J. \& Williams, P. M. (1996). Real time quantitative PCR. Genome Res 6, 986-994.

Holt, J. G., Krieg, N. R., Sneath, P. H. A., Staley, J. T. \& Williams, S. T. (1994). Bergey's Manual of Determinative Bacteriology, 9th edn. Baltimore: Williams \& Wilkins.

Hugenholtz, P., Goebel, B. M. \& Pace, N. R. (1998). Impact of culture-independent studies on the emerging phylogenetic view of bacterial diversity. J Bacteriol 180, 4765-4774.

Johnson, M. J., Thatcher, E. \& Cox, M. E. (1995). Techniques for controlling variability in Gram staining of obligate anaerobes. $J$ Clin Microbiol 33, 755-758.

Klappenbach, J. A., Dunbar, J. M. \& Schmidt, T. M. (2000). rRNA operon copy number reflects ecological strategies of bacteria. Appl Environ Microbiol 66, 1328-1333.

Klausegger, A., Hell, M., Berger, A., Zinober, K., Baier, S., Jones, N., Sperl, W. \& Kofler, B. (1999). Gram type specific broad-range PCR amplification for rapid detection of 62 pathogenic bacteria. J Clin Microbiol 37, 464-466.

Kroes, I., Lepp, P. A. \& Relman, D. A. (1999). Bacterial diversity within the human subgingival crevice. Proc Natl Acad Sci US A 96, 14547-14552.

Lyons, S. R., Griffen, A. N. \& Leys, E. J. (2000). Quantitative realtime PCR for Porphyromonas gingivalis and total bacteria. J Clin Microbiol 38, 2362-2365.

Marchesi, J. R., Sato, T., Weightman, A. J., Martin, T. A., Fry, J. C., Hiom, S. J. \& Wade, W. G. (1998). Design and evaluation of useful bacterium-specific PCR primers that amplify genes coding for bacterial 16S rRNA. Appl Environ Microbiol 64, 795-799.

Massey, W. L. K., Romberg, D. M., Hunter, N. \& Hume, W. R. (1993). The association of carious dentine microflora with tissue changes in human pulpitis. Oral Microbiol Immunol 8, 30-35.

Miller, J. H. (1972). Experiments in Molecular Genetics. Cold Spring Harbor, NY: Cold Spring Harbor Laboratory.

Neidhardt, F. C., Ingraham, J. L. \& Schaechter, M. (1990). Physiology of the Bacterial Cell. A Molecular Approach, Chapter 14, pp. 389-417. Sunderland, MA: Sinauer Associates.

Relman, D. A., Schmidt, T. M., MacDermott, R. P. \& Falkow, S. (1992). Identification of the uncultured Bacillus of Whipple's disease. New Eng J Med 327, 293-301.
Rupf, S., Merte, K. \& Eschrich, K. (1999). Quantification of bacteria in oral samples by competitive polymerase chain reaction. J Dent Res 78, 850-856.

Schmidt, T. M., Pace, B. \& Pace, N. R. (1991). Detection of DNA contamination in Taq polymerase. Biotechniques 11, 176-177.

Suzuki, M. T., Taylor, L. T. \& DeLong, E. F. (2000). Quantitative analysis of small-subunit rRNA genes in mixed microbial populations via 5'-nuclease assays. Appl Environ Microbiol 66, 4605-4614.

Syed, S. A. \& Loesche, W. J. (1972). Survival of human dental plaque flora in various transport media. Appl Microbiol 26, 459-465.

Tao, L. T., MacAlister, J. \& Tanzer, J. M. (1993). Transformation efficiency of EMS-induced mutants of Streptococcus mutans of altered cell shape. J Dent Res 72, 1032-1039.

US Department of Health and Human Services - Centres for Disease Control (1982). Media for the isolation, characterization and identification of obligately anaerobic bacteria. Washington, DC: USGPO.

Veal, D. A., Deere, D., Ferrari, B., Piper, J. \& Attfield, P. V. (2000). Fluorescence staining and flow cytometry for monitoring microbial cells. J Immunol Methods 243, 191-210.

Ward, D. M., Weller, R. \& Bateson, M. M. (1990). $16 \mathrm{~S}$ rRNA sequences reveal numerous uncultured microorganisms in a natural community. Nature 345, 63-65.

Wilson, K. H., Blitchington, R. B. \& Greene, R. C. (1990). Amplification of bacterial $16 \mathrm{~S}$ ribosomal DNA with polymerase chain reaction. J Clin Microbiol 28, 1942-1946.

Wintzingerode, F. V., Göbel, U. B. \& Stackebrandt, E. (1997). Determination of microbial diversity in environmental samples: pitfalls of PCR-based rRNA analysis. FEMS Microbiol Rev 21, 213-229.

Yanisch-Perron, C., Vieira, J. \& Messing, J. (1985). Improved M13 phage cloning vectors and host strains: nucleotide sequences of the M13mp18 and pUC19 vectors. Gene 33, 103-119.

Zerr, M. A., Cox, C. D., Johnson, W. T. \& Drake, D. R. (1998). Effect of red blood cells on the growth of Porphyromonas endodontalis and microbial community development. Oral Microbiol Immunol 13, 106-112.

Received 1 June 2001; revised 19 August 2001; accepted 4 September 2001. 